\title{
Om at bygge skoler, bestemme skrift og varetage hygiejne som udtryk for samme habitus
}

\author{
Britta Siegumfeldt
}

\section{Læger, videnskab og sundhed}

\begin{abstract}
Når vi nu [...] ser, at alle væsentlige Ulemper kunne fjernes fra Skolerne og Disse indrettes således, at de bliver et sundt og godt Opholdssted, hvor Børnenes Helbred ikke er udsat for nogen væsentlig Fare, da har Børnene et bestemt Krav på, at alle Hensyn tages for at skaffe dem så gunstige Forhold som muligt. (Hertel, 1880)
\end{abstract}

Lægen Axel Hertel arbejdede ud fra den indstilling, som er udtrykt i ovenstående citat - ingen tvivl om det. Min opgave her vil, ud over at være et fors $\emptyset$ g på at beskrive hans arbejde, være en analyse af, hvordan en professionskultur, lægens, på én gang arbejder efter en åbenbar, historisk bestemt fornuft og samtidig - uden at have det som sit bevidste program - er med til i skolens børn at inkorporere eller overføre nogle "logikker", nogle bestemte måder at tænke, handle og forstå sig selv og verden på, som er typiske for lægernes egen klasse og hele profession.

\section{Axel Hertel - læge og hygiejniker}

Hertel blev født i 1840, tog studentereksamen i 1858 og derefter lægeeksamen ved København Universitet i 1865. Efter i nogle år at have arbejdet som læge forskellige steder - som underlæge i hæren i 1864, ved Kommunehospitalet i København 1865-68, fire måneder ved Sankt Hans Hospital i Roskilde i 1868 - var han i udlandet i godt et år for at supplere sin uddannelse ved forskellige hospitaler, hvorefter han blev ansat som reservelæge ved Kommunehospitalet fra juni 1869 til januar

Artikkelen er tidligere publisert på sidene 113-135 i Petersen (1995).

Publisert: 08.09.2020

Praxeologi - Et kritisk refleksivt blikk på sosiale praktikker @2020 Britta Siegumfeldt

DOI: http://dx.doi.org/10.15845/praxeologi.v2i0.3132 
1871. Derefter forlod han hospitalsverdenen, blev praktiserende læge, distriktslæge og maj 1872 kommunelæge i København, en stilling, som han havde indtil december 1910, hvor han gik af som $70-$ årig og $\mathrm{d} \varnothing$ de kort efter. I forbindelse med dette arbejde fik han lejlighed til at udforske og arbejde med børns udvikling og vilkår i samtidens skoler, private såvel som offentlige. Han agiterede for at få indført skolelægeordninger ved alle skoler, og efter at en forsøgsordning havde fungeret i et par år i Københavns kommune, blev han i 1897 opfordret til selv at søge en af de nye stillinger. Derefter havde han, samtidig med at han passede sit arbejde som kommunelæge, også fast tilsyn med to kommuneskoler. Inden for lægevidenskab og hygiejne skete der store udviklinger i perioden, og Axel Hertel følte sig som del af den moderne udvikling. Den klassiske modsætning imellem lægevidenskabens og hygiejnens udøvere, hvor lægens opgave er at helbrede den syge, mens hygiejnikerens er at forebygge sygdom og bevare sundhed, var ved at være ophævet, og han yndede da også at underskrive sig således: "Axel Hertel, Læge og Hygiejniker".

Hertel er, vil jeg påstå, typisk for en bestemt profession i en bestemt historisk epoke. Han er af borgerlig herkomst (embedsmandsborgerskab), har studentereksamen, universitetseksamen, og et vigtigt led i hans uddannelse/dannelse er udlandsrejserne til de bedste hospitaler og læresteder $\mathrm{i}$ Europa. Ud over at have den lægefaglige kompetence er han også sprogligt kompetent, f.eks. læser og skriver han på artikler i både tyske, engelske og franske fagtidsskrifter, og han havde ifølge lægen Poul Hertz' mindeartikel også skønlitterære interesser (Hertz, 1928). Politisk var Hertel konservativ med en humanistisk indstilling, som gav sig udslag $i$ hans interesse for sociale forhold. Dette var alt sammen "almindeligt" for danske læger i den periode, jeg beskæftiger mig med, og min interesse for ham er netop heller ikke hans særlige meritter, men at han er eksemplarisk for en bestemt profession med hensyn til klasse, opdragelse, skoling og dannelse og politisk holdning. Selvom han er den, der almindeligvis beskrives som og fremhæves som "skolehygiejnens skaber", ifølge ovennævnte artikel af Hertz, så er han ikke den, der siger noget særligt nyt eller originalt i forhold til, hvad andre før ham har sagt om skole og hygiejne. Blot har en ny historisk epoke, nye objektive omstændigheder - politiske, økonomiske, videnskabelige m.m. - kædet sammen med hans meget store arbejdsevne og flid med hensyn til at formulere sig offentligt, mundtligt såvel som skriftligt, ${ }^{1}$ gjort sit til, at netop han kommer til at fremstå for eftertiden som den, der skabte skolehygiejnen $\mathrm{i}$ Danmark.

\section{Udviklinger inden for medicin og hygiejne}

Fra 1870'erne fik læren om sygdom og sundhed et nyt indhold. Under indtryk af de ny videnskabelige opdagelser udviklede der sig teorier og teknikker, hvormed man kunne identificere, forklare og udrydde en række sygdomme hos mennesket. Dette bet $\varnothing$ d, at det i højere grad end tidligere blev selve den menneskelige krop, dens enkeltdele og disses sygdomme, der tiltrak sig lægernes interesse. En egentlig lægeprofession etablerede sig, og mange af de lægelige specialer, som vi kender i dag, opstod i perioden. Samtidig var der en samfundsmæssig interesse i at udvikle og bevare en sund befolkning, som blev stærkere henimod århundredskiftet, og som influerede på de teorier, der blev udviklet.

Den gamle teori om sygdom og sundhed, som koncentrerede sig om omgivelsernes betydning for sundheden, var teorien om miasmerne. Den gik ud på, at sygdom opstod på steder med fordærvet luft - opstod af luften så at sige, f.eks. ved kirkegårde, sumpede steder, kloakker og i offentlige bygninger, hvor mange mennesker var forsamlede. Ved opdagelsen af bakterierne i mikroskopet materialiserede det sygdomsfremkaldende stof sig; det blev synligt og kunne beskrives og

\footnotetext{
${ }^{1}$ En bibliografi, som jeg er i færd med at udarbejde, tæller indtil videre 67 titler.
} 
klassificeres. Den ny viden om bakterier og deres virkning og vækst affødte nye og effektive teknikker, antiseptik og aseptik, til bekæmpelse af infektionssygdomme.

I de skolehygiejniske emner, som jeg vil tage op, blev viden fra nye lægespecialer taget i brug. Gynækologien fik op imod århundredskiftet st $ø$ rre indsigt i og viden om den kvindelige cyklus, udvikling og reproduktive organer, og nye teorier blev til, der kunne forklare kvinders "anderledeshed" (Rosenbeck, 1987). Disse blev bl.a. brugt til legitimering af skolepigers sygelighed. Arvelighedslæren var i sin vorden. Med dens resultater i hånden blev det muligt at kunne sige noget om, hvilket afkom, der ville blive "degeneret", dvs. hvilke kvinder, der ikke burde føde børn. Desuden blev den brugt til at differentiere og klassificere børn med henblik på deres udskillelse af normalbefolkningen som unormale (Kirkebæk, 1993). Oftalmologien, dvs. Iæren om øjet, udviklede en egentlig videnskabelig fremgangsmåde, efter at øjespejlet blev opfundet af lægen Helmholtz i 1851. Øjensygdomme var i fokus for skolehygiejnikerne, da unders $\varnothing$ gelser viste, at mange børn led af kraftig nærsynethed.

Inden for den sundhedsbevægelse, som henimod århundredskiftet voksede sig stærk i borgerskabet, blev populariseringen af lægevidenskab og hygiejne en vigtig opgave. Her var det først og fremmest kampen imod bakterierne, det handlede om. I sundhedstidsskrifter som Dansk Sundhedstidende er der f.eks. artikler om, hvor de findes, hvordan de bekæmpes, hvad de vejer, hvor hurtigt de vokser, deres mængde i tal osv. Her er også forholdet til huden, og hvad der måtte befinde sig på den af små synlige og især usynlige organismer meget fremme. Daglig vask og grundig frottering er budskabet til bekæmpelse heraf. Sundhedsbevægelsens aktører er endvidere meget optaget af fordøjelsen; de omtalte tidsskrifter er en ren guldgrube i studiet af skræk- og på samme tid fascinationsforestillinger vedrørende forstoppelse; og også luftens og blodets omløb eller mangel herpå er populært stof. Disse sidste emner optræder ikke som egentlige skolehygiejniske problemer, så de bliver blot nævnt her; men figuren i dem vil jeg vende tilbage til.

\section{Hertel og skolehygiejnens gennemslag}

Overordnet for Hertels arbejde med skolebørn og sundhed var det synspunkt, som han delte med andre skolehygiejnikere, at skolen på forskellige måder var årsag til børnenes sygelighed, dvs. årsag til at de ikke udviklede sig kraftigt nok, hverken fysisk eller mentalt. Han mente selv, at de statistikker, som han gennem de mange år som kommunelæge førte over børnepatientemes højde og vægt, bekræftede dette. I 1882 blev han medlem af den såkaldte Skolehygiejniske Kommission, som herhjemme gennemførte en meget stor og landsomfattende undersøgelse af skolebørn, og hvis resultater viste en bekymrende sygelighed blandt skolebørn generelt (Betænkning, 1884). Kommissionen havde, ud over at undersøge sygeligheden og skolernes fysiske rammers beskaffenhed, også den opgave at udstikke retningslinier for de ønskede fysiske rammer for skolen; og i de ny skoler, som blev bygget af Københavns kommune i årene derefter, blev disse skolehygiejniske overvejelser inkorporeret; arkitekter for skoler og andre offentlige bygninger tog $\mathrm{i}$ højere og højere grad hensyn til hygiejnen og de lægelige direktiver. ${ }^{2}$

Allerede i 1850'erne var Københavns kommune begyndt at bygge skolebygninger efter sundhedsmæssige direktiver. Der blev da fastsat bestemte mål for, hvor meget rum og hvor meget lys, der skulle være pr. elev i et klasseværelse. Samtidig skulle skolen, i modsætning til hvad der tidligere var det almindelige i København, helst også være et særligt hus, som ved sin arkitektur muliggjorde en opdeling af børnene i klasser, samt en deling af de to køn. Den nye skolehygiejniske

\footnotetext{
${ }^{2}$ Københavns kommune udgav $\emptyset \emptyset$ bende beskrivelser af skolerne med tegninger og tekst, se Kjøbenhavns Magistrat (1846-1903).
} 
indstilling, som for alvor holdt sit indtog i perioden 1880-1900, førte med sig, at de måder at bygge skoler på, som på det tidspunkt var blevet det almindelige i storbyen, nu blev nuanceret og "forbedret"; og at diskursen og dermed begrundelsen, blev en anden. Det handlede nu især om bestemte ting såsom lysets, luftens, varmens, renlighedens og gangliniernes "fornuft", således: Lyset skulle komme fra solen; af hensyn til børnenes $\varnothing$ jne burde det være klart og utvetydigt, måtte f.eks. ikke have den "flimren", som lysindfald gennem vinduer med sprosser kunne give; og indfaldet skulle komme fra venstre i forhold til klassens retning, så man undgik skygger på bordet. Varmen skulle være ensartet og kontrollerbar, og den nyeste teknik, caloriferen, blev derfor taget i brug, hvilket betød, at opvarmet luft kunne cirkulere i klassen og fordele varmen ligeligt til alle. Friskluftkanaler blev installeret samtidig med varmluftkanalerne. I umiddelbar tilknytning til klasseværelserne blev der bygget små forstuer, der fungerede som garderober, hvori børnene skulle lægge deres overtøj, træsko og madpakker fra sig. Meningen var, at den dårlige luft, der kunne opstå omkring disse ting, skulle holdes ude fra luften i klasseværelserne. Miasmeteorien lever således side om side med de ny teorier!

Overalt i de industrialiserede lande i Europa interesserede man sig på lignende måde som i Danmark for skolebørns sundhed. Hertel kendte til dette arbejde og havde kontakter med udenlandske hygiejnikere. Som repræsentant for den skolehygiejniske kommission foretog han studierejser til skoler i de lande i Europa, som var længst fremme med hensyn til skolehygiejnen: Belgien, Frankrig, Schweiz, Østrig og Tyskland.

Gennem Hertels artikler og foredrag og i de følgende debatter, som han deltog aktivt i, taler en holdning som man kunne kalde folkehygiejnisk med nøglebegreber som "Styrke", "Kraft", "Liv", "Udvikling".

\section{Analyse af tre skolehygiejniske debatter}

\section{Første debat - "Vort Skolemateriel"}

I de unders $\varnothing$ gelser af skolebørns sygelighed, som blev sat i værk i perioden, blev der konstateret mange dårlige rygge; det gjaldt skoleelever i alle aldre - og jo flere skader, jo længere tid de havde gået i skole. Disse rygge var, således lyder beskrivelserne: "snoede", "drejede", skæve, "krumme", hvorimod den sunde ryg efter lægers mening skulle være: "lige", "ret", "rank" og "stiv". Den danske læge og rygspecialist A. G. Drachmann havde tidligere beskæftiget sig med sammenhængen imellem dårlig ryg og dårlige møbler i skolen; men først omkring 1880 blev emnet debatteret offentligt (Mehldahl, 1879-80, Levy, 1879 og Ulrik, 1880). Også Axel Hertel deltog i debatten. At årsagen til de mange dårlige rygge måtte findes i skolernes indretning var han overbevist om; hans holdning var, at dette kunne og burde man gøre noget ved.

I 1880 tog han tråden op, hvor Drachmann slap, i en længere artikel i Berlingske Tidende med titlen "Vort Skolemateriel" (Hertel, 1880); og siden hen beskæftigede han sig med emnet i mange andre artikler og ved mange forskellige lejligheder. På det tidspunkt var der især i vore nabolande mange eksperimenter i gang for at fremstille møbler til skolebrug. I udlandet blev der tegnet og konstrueret nye borde, bænke og stole; i Paris og St. Petersburg havde man lavet store udstillinger, hvor de forskellige typer blev vist frem. I første del af den omtalte artikel gennemgår han det inventar, som han har set i de mange københavnske skoler, som han i sin egenskab af skolekommissionsmedlem besøgte. Det bestod, beretter han, ofte af borde og bænke, hvorpå eleverne sad mere eller mindre tæt, afhængigt af, hvor mange der var, oftest en 6-8 stykker på samme bænk. Også Iøse stole eller skamler blev brugt. Alt var i voksen-st $\varnothing r$ relse og ofte gamle 
møbler, der var blevet tilovers andetsteds. ${ }^{3}$ De skoler, som blev bygget af Københavns kommune i sidste halvdel af 1800-tallet havde dog særlige skole-møbler, men hverken disse eller de førnævnte arrangementer levede op til de moderne hygiejniske krav til et godt skolebord. Hertel agiterer $\mathrm{i}$ artiklen for, at møbler til skolebrug burde passe til børnenes kropsdimensioner. Han analyserer selve siddestillingen og beskriver reglerne for det rette møblement således:

Bænkens Højde bestemmes ved at måle Højden fra Gulvet til Knæhasen, når Barnet sidder med Benet bøjet i ret Vinkel og Fødderne hvilende på Jorden; Bænkens Bredde må være så stor, at tre femtedele af Låret er understøttet. Bordets Højde over Bænken bestemmes ved, når Barnet sidder ret op på Bænken, at tage Afstanden fra denne til Albuen og dertil lægge 1 à 2 Tommer (...). (Hertel, 1880)

Derudover handler det især om afstanden til øjnene, st $\varnothing$ tte til lænden og plads til siden at røre sig frit. Alt blev beskrevet i mange detaljer i lighed med ovenstående citat.

Debatten i Berlingske Tidende, hvor især en anden læge er uenig med Hertel, handlede især om, hvorvidt opholdet i skolen var mere skadeligt for børnenes helbred end opholdet i hjemmet, og man diskuterede hjemmenes standard for renlighed, frisk luft og møblering sammenlignet med skolens. Også det samlede antal timer, som børnene tilbragte henholdsvis det ene sted og det andet blev sammenholdt og diskuteret. Lægerne var ikke enige om disse ting - men de hygiejniske regler for skolemøblernes konstruktion var de enige om - de var nemlig blevet bevist gennem fors $\varnothing \mathrm{g}$ og statistikker og havde nærmest karakter af grundlæggende love. Hertel skriver f.eks.:

(...) har vi herhjemme så længe holdt os uden for Diskussionen om Skolemateriellet, så har vi på den anden Side den Fordel, at Hovedprincipperne, hvorefter dette bør indrettes, nu efter langvarige Fors $\varnothing g$ andre Steder er fuldstændig fastslaaede og, hvad der er sjældent, at der må siges at være opnaaet fuld Enighed om, hvorledes det skal være. (Hertel, 1880)

Hermed mener han, at sagen er "bevist" - i positiv og statistisk forstand. Denne holdning er karakteristisk for ham; det er den "moderne" naturvidenskabsmand, der taler.

En bestemt detalje ved konstruktion af skoleborde blev gjort til genstand for megen diskussion og mange fors $\emptyset \mathrm{g}$ blandt hygiejnikere både i Danmark og i de europæiske lande, vi taler om - og Axel Hertel var naturligvis på banen, bl.a. i artiklen i Berlingske Tidende. Det handler om afstanden mellem bord og bænk - horisontalt. Bordene skulle konstrueres således, at børnene på én gang kunne sidde rigtigt, dvs. nå gulvet, rigtig højde, støtte for lænden, plads til siden osv. (et hygiejnisk krav) - og på samme tid således, at der blev plads til, at de ved overhøring, ved tiltale o.lign. hurtigt kunne rejse sig op og stå ret (et pædagogisk krav). Det sidste krævede en positiv afstand - det første en negativ afstand på dette sted. I næsten alle de mange overleverede tegninger af skoleborde, som blev produceret i de år, både danske og udenlandske, har man forsøgt at tage hensyn til disse to hinanden modstridende forhold: ${ }^{4}$ Man kunne f.eks. sikre den rette afstand ved at bord og bænk var bygget sammen; bordpladen evt. bænken, kunne så laves opklappelig, forskydelig, sammenskubbelig el.lign., så der, når det blev nødvendigt, kunne blive den nødvendige plads. Og man kunne anbefale én- evt. tomandsborde samt gode mellemrum mellem rækkerne, således at børnene blot behøvede at træde ud til siden og stå ret imellem bordene i stedet for "på" deres plads.

\footnotetext{
${ }^{3}$ Ifølge Hertel gjaldt dette især i private skoler, og hos private undervisere, hvis "skolerum" også var underlagt skolekommissionens tilsyn.

${ }^{4}$ På Danmarks pædagogiske Bibliotek, Lers $\emptyset$ Park Allé, Kbh. findes en stor samling tegninger af både danske og udenlandske skolemøbler fra perioden. (Danmarks pædagogiske Bibliotek befinder sig i 2020 i den tidligere Danmarks Lærerhøjskoles bygninger i Emdrupborg.)
} 


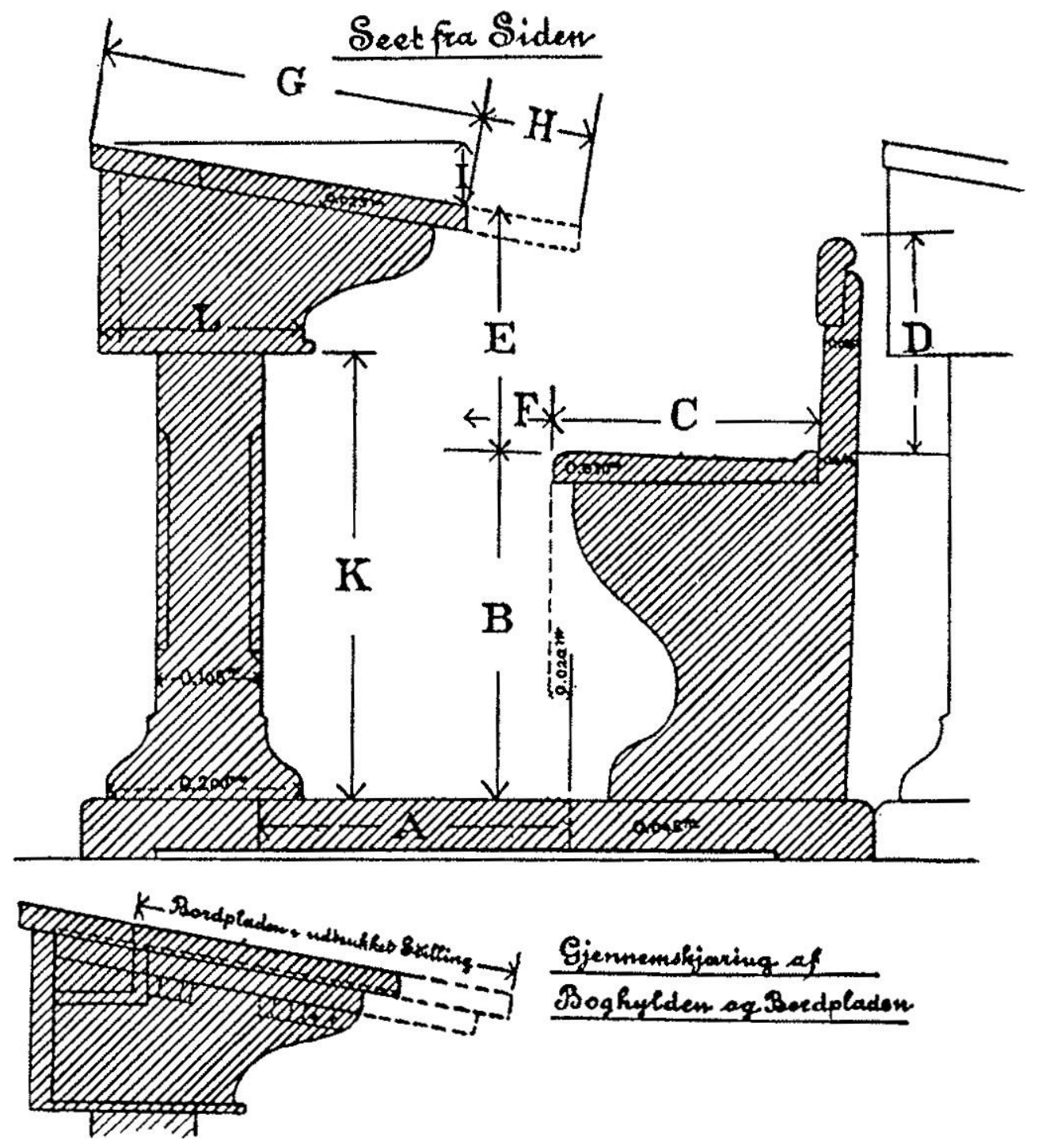

Figur 1: To-sædig skolepult, set fra siden.

Kilde: Dansk skolemuseum, Christian Glenstrup

Skoleklasserne og bordene kom faktisk til at se sådan ud, som hygiejnikerne ønskede, f.eks. i de 20 store nye kommuneskoler, som blev bygget i København alene i perioden 1880-1900. Jeg har selv siddet i sådanne klasser og ved sådanne borde som barn, og mange år senere har jeg undervist andre børn i dem. Kompromisset, en nulafstand mellem bænk og bordplade, blev det almindelige.

Figurer: ${ }^{5}$ I diskussionen handler det om, hvordan et skolebord bør konstrueres, så børnene ikke får skæve rygge. Her ser vi, hvordan en ganske bestemt afstand mellem bord og bænk tiltrækker sig megen opmærksomhed, og hvordan man i løsningen af et problem fokuserer på denne afstand samt finder en løsning, som både fastlægger afstanden mellem bord og bænk og også skaber en afstand til siden. At skille ad og holde afstand er karakteristisk for periodens praktikker, hvad enten det drejer sig om læge-, skole- eller arkitektpraktikker; enmandsbordet, som effektivt adskiller eleverne fra hinanden, var f.eks. det i hygiejnisk henseende rigtigste bord (begrundelse: bakterier, smittefare).

${ }^{5}$ Når man arbejder med, dvs. læser og tænker over, en professions praktikker, hvoraf mange i dag virker fremmedartede, er der nogle logikker for fremgangsmåde, nogle typiske måder at gribe problemerne an på, nogle bestemte strategier, som går igen, og som ikke er bevidste for aktørerne. En sådan typisk logik for tænkning, handling og opfattelse af et problem kalder jeg her en "figur". 
Lærer og elev befandt sig på forskellige planer i rummet, henholdsvis katederforhøjning og gulv, og i hver sin ende af klasseværelset. I skolearkitekturen ser vi også, hvordan adskillelsen, eller forskellen, er understreget: skolehuset er på mange måder anderledes end den øvrige bybebyggelse, det er trukket lidt tilbage fra gadelinien og har både en anden højde end, og en vis afstand til det omgivende byggeri. Rundt om skolegården er der et højt plankeværk, som afgrænser og adskiller skolen yderligere fra den omkringliggende by. Foran de enkelte klasseværelser blev der indrettet små forstuer, hvor madpakker og overtøj skulle være. Hvert barn havde sin egen afgrænsede hylde og knage. Den ændring i holdning og praksis med hensyn til byggeri, inventar og møblering, som fulgte med skolehygiejnen, understreger med andre ord en tilbøjelighed hos skolehygiejnikerne til at lave adskillelser.

\section{Anden debat - "Lodret eller skraa Skrift"}

I periodens store unders $\varnothing$ gelser af skolebørns sundhedstilstand interesserede man sig bl.a. for de nærsynede børn, og man fandt mange med lidelsen, som man mente stammede fra det såkaldte "Nærarbejde", altså skrivning, læsning, håndarbejde o.lign. Skolehygiejnikerne arbejdede meget med at finde ud af, hvilke forholdsregler man kunne tage for at undgå denne sygdom. I en debat om skrivningens hældning, som var fremme i de danske pædagogiske og hygiejniske tidsskrifter $\mathrm{i}$ 1890'erne, bevæger Hertel sig i højere grad end i skolemøbeldebatten ind på lærernes gebet: deres undervisning. Samtidig er det også, i modsætning til den forrige debat, et område, hvor det kan nytte at agitere for en bedre hygiejne, da det ikke koster penge for skolevæsen eller skoleholder at ændre skriften fra skrå til lige, skriver han i sin første store artikel om problemet i 1893 (Hertel, 1892). Han var allerede opmærksom på spørgsmålet i 1883, da han rejste rundt i Europa og undersøgte de hygiejniske foranstaltninger i forbindelse med skolegang. I sin rapport herfra beskrev han nogle tyske fors $\varnothing \mathrm{g}$ med andre skriftformer (Hertel, 1883); men først ca. 10 år senere var der tilsyneladende rigtig grobund for debat og fors $\varnothing$ g herhjemme. Udgangspunktet for artiklen er de mange klager fra lærere over "den store Vanskelighed, det har at faa Eleverne til at sidde i naturlige, ikke direkte skadelige Stillinger under Skrivningen" - til trods for lærernes anvisninger og de rette møbler og lysforhold (Hertel, 1892). De sundhedsmæssige farer, som truede skolebarnet, var ifølge hygiejnikerne, ud over nærsynethed og skæv ryg, følgende: åndedrættet og blodcirkulationen blev hindret, hvilket gav "Blodoverfyldning" på grund af de sammenpressede organer og kunne føre til dårlig fordøjelse samt i overgangsalderen være skadeligt for kønsorganernes udvikling og funktion; manglende blod til hjernen kunne medføre næseblod og hovedpine! Her er tale om en fortsættelse og opstramning af skolemøbel-debatten, som, siger Hertel i omtalte artikel, netop af den grund ikke er fuldt ud afsluttet.

De gældende regler for skrivningens hygiejne var beskrevet såvel i skoleloven af 1814 som i Anordningen om Borger- og Almueskolevæsenet i Kjøbenhavn af 1844, men var her blot nedfældet som advarsler mod at lade børnene sidde i stillinger, der gav anledning til dårlig skrift eller dårligt helbred. Gængs viden og praksis handlede om, at lyset skulle ind fra venstre, og at bordene skulle have en "passende" højde. Men med en ny "videnskabelig" fremgangsmåde for fremstillingen af den rette skrivestilling kunne årsagerne præciseres helt anderledes; og det så Hertel som en vigtig opgave. I forlængelse af og som en udvikling af Drachmanns analyser af ryglidelser, analyserede Hertel selve akten "at skrive" i den omtalte artikel. Alle muligheder for skrivebogens placering på bordet: til venstre, til højre, midt for, skrå, lige og disse stillingers konsekvenser for ryggens, henholdsvis hovedets holdning, gennemgås. Den rette, lige, lodrette ryg, det let bøjede hoved med en tænkt linie mellem de to øjne parallel med bordkanten er den korrekte stilling, hvis man skal undgå drejninger i rygsøjlen. Skulderens bevægelse, underarmens støtte, armenes parallelforskydning, håndleddet evt. albuen som centrum for bevægelsen blev analyseret med henblik på en forståelse af deres funktion i skriveprocessen. Der blev også lagt vægt på, at de to 
øjnes afstand til det skrevne skulle være ens; ellers var der fare for, at man blev nærsynet - i hvert fald på det ene øje, det, der havde forkert afstand til det skrevne - og der blev lagt vægt på, at en tænkt linie mellem de to øjne skulle være parallel med de skrevne linier.

Skriftens hældning har betydning for de ovenfor nævnte variable, mente man. Og her er igen flere muligheder: den lodrette skrift, de mange mere eller mindre skrå, målt i grader i forhold til den lodrette nedstreg (i Danmark var 45 grader, som er en meget skrå skrift, almindeligt på den tid); og endelig er der den mulighed, at den skrå skrift kan fremkomme ved, at det lodrette, hygiejnisk korrekte træk kombineres med, at skrivebogen bliver lagt på skrå (den i min skoletid almindelige fremgangsmåde!). Det at skrive blev altså af hygiejnikeren beskrevet som et overmåde indviklet maskineri, hvor hvert enkelt led eller del havde sin bestemte funktion og betydning og kunne rettes ind for sig. Konklusionen måtte (næsten nødvendigvis) blive: lodret skrift er mindst skadelig! I debatten, som mange skrivelærere deltog i, var der da heller ikke nogen af skråskrifttilhængerne, som forsvarede deres holdning med sundhedmæssige argumenter; det gik mere på hastigheden og udseendet, den "personlige" håndskrift. Lodretskrifttilhængerne havde de tilsyneladende kraftigste argumenter: de gik ind for den oprindelige, i betydningen den "gamle" og den "naturlige" skrift, samtidig med, at de havde den "moderne" lægevidenskab, bl.a. repræsenteret ved Hertel og øjenspecialisterne, på deres side.

Pædagogisk Selskab nedsatte i begyndelsen af 1890'erne et 9-mands udvalg af sagkyndige, læger og skrivelærere, som skulle unders $\varnothing$ ge spørgsmålet nærmere. Hertel var et af medlemmerne. Dette udvalg satte et kontrolleret fors $\emptyset$ g i gang på 12 københavnske skoler, hvori de fulgte nogle klasser, som skrev enten skråt eller lodret igennem så lang en periode, at man kunne se udviklinger. Resultatet gav stort set udtryk for den samme holdning, som var Hertels: at lodret skrift var den hygiejnisk korrekte, men at en moderat skrå (op til $25^{\circ}$ ), hvor bogen er skråt anbragt på bordet og nedstregen lodret, også kunne anbefales. Der blev i betænkningen, hvori der var en overvægt af skolefolk, endvidere lagt vægt på "Lærerens Personlighed" som værende af endnu større betydning end det rette skolemateriel (Betænkning, 1896, s. 10). Læreren skulle altså med sin autoritet kunne fastholde børnene i den rette stilling. Denne var nøje beskrevet; en skrivebog fra perioden kunne f.eks. have følgende indskrift på omslaget (i uddrag):

Legemets Stilling:

1. Legemet maa hvile paa hele Sædet. Fødderne maa støttes med hele Fodsaalen mod Gulvet eller Fodstykket. Kroppen saa lodret som mulig med begge Skuldrene parallelle med Randen af Bordet. Brystet maa ikke støttes mod Bordet. Hovedet let Bøjet, ikke drejet til nogen af Siderne; Øjnenes Afstand fra Skriften maa omtrent være 12 Tommer.

Armenes og Hændernes Stilling:

1. Begge Armene hænge naturlig ned til siden; Albuerne ikke drejede fremefter. Begge Underarmene hviler i 2/3 af deres Længde paa Bordet og pege hen mod Midten af Linien, saa at de danne en ret Vinkel. Begge Albuer Staa omtrent en Haandsbred fra Kroppen.

(..)

Bogens stilling:

5. Midten af Linien ligger lige for Midten af Kroppen. Linien selv maa være parallel med Randen af Bordet

6. Ved Skrivning efter Forskrift eller en Bog maa Forskriften eller Bogen ligge lige over, ikke ved Siden af Skrivebogen.

(Ulrichsen, 1893)

Hele denne debat fik bl.a. de følger for skriveundervisningen, at stillings $\varnothing v e l s e r$, hvor håndens, armens og kroppens stillinger blev ind øvede hver for sig, blev til en fast bestanddel af 
skriveundervisningens metodik, og senere, f.eks. i Pedersen og Thomsens Skrivesystem, som blev genoptrykt år efter år fra 1927 til 1950'erne, i forenklet form blev påtegnet de skrive- og øvehæfter, der blev anvendt.

Figurer: I denne debat er det spørgsmålet om en skrifts udseende og muligheden for at kunne udføre skrivningen uden at få ondt i ryggen eller at blive nærsynet, som er til debat. Her genfinder vi nogle af mønstrene fra den første debat.

En figur, som kan aflæses af praktikkerne, er forestillingen om det lodrette, det lige og det symmetriske, som i skolebordsdebatten blot var en fornuft, der gik på ryggens/kroppens almindelige siddestilling. Optagetheden af det symmetriske ser vi bl.a. i ovenstående citat om den rette skrivestilling. Rygraden og dens lodrette linie tænkes her fortsat ud over bordet som den akse, omkring hvilken symmetrien spejler sig: de to øjne, armenes og benenes stilling, skuldrene, bordets sider og endelig hovedet i selve aksen. At de ny skolebygninger er tænkt og opfattet bevidst symmetriske i såvel ydre fremtoning som indre planløsning, viser tegningerne tydeligt. Også i det talesprog, som debattørerne anvender, ser vi det lodrette som det "naturlige" og det skrå/skæve som det "farlige"; en lærer skriver f.eks. et sted: "Der går her en lige linie fra skraa Skrift til skævkørt Liv".

I debatten om skrivning ses også en anden karakteristisk figur: at dele op og isolere. Den er åbenlyst på færde i skrivemetodikken, hvor de enkelte træk skal læres og ind øves enkeltvis - det blander hygiejnikeren sig ikke i. Men han bruger fremgangsmåden med at dele op og se på enkeltdele af en helhed $\mathrm{i}$ sin analyse af kroppen, både i relation til skolebordet og i relation til skrivningen, jf. de to afsnit. Denne figur er en hovedfigur i det "moderne" naturvidenskabelige eksperiment: at isolere objektet og manipulere med det; og den er logikken i de for perioden vigtige nye lægevidenskabelige teknikker til udryddelse af sygdom og $d \varnothing d$ i perioden. At isolere eller markere det syge sted - både når man skal operere, og når man skal anvende antiseptiske og aseptiske metoder - er den grundlæggende fremgangsmåde.

\section{Tredie debat - "Pigers Sygelighed"}

Fors $\varnothing \mathrm{g}$ med henholdsvis fælles og kønsadskilt undervisning og deres skolehygiejniske konsekvenser dukker op og bliver ført i mange forskellige sammenhænge og til forskellige tider i mange af de lande, vi normalt sammenligner os med, f.eks. i Tyskland og Sverige. I slutningen af 1800-tallet havde vi en debat herom i Danmark, en debat, som først og fremmest blev ført i den såkaldt højere skoles regi: imellem lærere for de statslige drengerealskoler og lærerinder i de private pigeskoler - og naturligvis skolehygiejnikere som Hertel. Diskussionen handlede bl.a. om, hvorvidt det var skadeligt sundhedsmæssigt og moralsk, eller måske præcis det modsatte, at undervise drenge og piger sammen, at sætte dem på samme skolebænk m.m.; men den havde også fokus på pigernes særlige "Sygelighed". 6

Et bestemt aspekt ved den fælles undervisning, "Aldersgrænseproblemet", blev diskuteret særlig intensivt fra slutningen af 1880 'erne og op til omkring århundredskiftet. Under overskrifter som, "Bør Aldersgrænsen til alm. Forberedelseseksamen nedsættes for Pigebørnenes vedkommende?" (1895) eller "Atter et Fors $\varnothing$ g på at rokke ved Aldersgrænsen" (1900) blev det taget op i tidsskrifter som Vor Ungdom og Bog og Naal. Problematikken udsprang af, at flere og flere piger i de år er blevet indskrevet på drengerealskoler for at tage eksamen. Ifølge den daværende skolelov skulle piger være 17 år, inden de indstillede sig til Alm. Forberedelseseksamen (præliminæreksamen), mens drengene normalt gjorde det, når de var 15 år gamle; pigerne skulle således gå to år mere i skole, før de gik op

\footnotetext{
${ }^{6}$ Jeg har tidligere analyseret debatten med udgangspunkt i antropologen Mary Douglas' teori om renhed og urenhed (Siegumfeldt, 1988).
} 
til samme eksamen. Det gav selvfølgelig skematekniske problemer for realskolerne, og man fors $\varnothing$ gte derfor ved en underskriftindsamling at få aldersgrænsen ændret, således at pigerne kunne gå op til eksamen samtidig med drengene. Modstanderne af dette forslag, hvortil Hertel hørte, fremførte som argument, at pigerne i skolen var mere syge end drengene - og allermest netop i puberteten. Såvel store udenlandske empiriske unders $\varnothing$ gelser som den Skolehygiejniske Kommissions unders $\varnothing$ gelse fra 1884 havde vist markante forskelle på pigers og drenges helbred. I den sidste blev f.eks. ca. 30 \% af drengene og $50 \%$ af pigerne betegnet som kronisk syge i 13-16-årsalderen. Der blev i hygiejnelitteraturen talt om fejl i centrale funktioner (hjerte, åndedræt, fordøjelse), om mangler (blod), deformiteter (kroppen), samt om manglende ligevægt (psykisk ubalance), alt sammen tegn på, hvad Hertel ville kalde for en for samfund og slægt skadelig "Svagelighed" eller "Kraftesløshed" (Hertel, 1880). Samme tankegang så vi også i skrivedebatten.

I Almenskoleloven fra 1903 blev princippet om fælles undervisning af de to køn vedtaget for mellemskolens vedkommende. ${ }^{7}$ Hertel frygtede, at de nye fællesskoler, som nu ville opstå, ville blive skoler, der med hensyn til undervisning blev indrettet som almindelige drengeskoler uden hensyn til, at piger havde andre "Krav", som han typisk kalder det, end drenge (Hertel, 1902). Han mente, at pigernes sygelighed kom af overanstrengelse på grund af for meget arbejde. Pigerne fra de borgerlige familier havde store arbejdsbyrder ud over skole og lektielæsning: fritidsundervisning i fag som dans, finere broderi, sprog og musik m.m.. Han taler om, at kroppen skal hærdes og styrkes, at der bør indføres flere praktiske og hygiejniske fag i skolen for pigerne (f.eks. sløjd og gymnastik). Samtidig mener han, at der bør ske en nedskæring af det teoretiske stof i undervisningen (Hertel, 1902).

Pigeskolens repræsentanter gik også ind i diskussionen af den nye lovs fællesskoleprincip. Men hvor Hertels holdning var den mere nuancerede, at et billede på skolen var hjemmet, hvori drenge og piger blev opdraget "sammen men ikke nødvendigvis ens", inddrog pigeskolelærerne ny og slagkraftige gynækologiske og arvehygiejniske teorier i deres argumentation for den rene pigeskole med et par års ekstra skolegang. Disse teorier fremstiller det som noget norrnalt, at piger $\mathrm{i}$ puberteten er sygelige. Specialist i kvindesygdomme, Howitz', teorier går f.eks. ud på, at pigernes evner simpelthen er nedsatte i puberteten, og at de i skolen ved for megen læsning kan skades for livstid på de reproduktive organer (Rosenbeck, 1987). Selvom det efter Howitz' mening er skolens opgave at styre udviklingen ind på "den rette Vej", så er for ham biologien det determinerende. Den ny arvelighedslære underst $\varnothing$ tter de gynækologiske teorier; den forklarer og beskriver følgerne af de opvoksende pigers, det vil sige de kommende mødres, svageligheder. Følgende citat handler om, hvordan de såkaldte "Nervesygdomme", som man mente blev dannet i puberteten, og som var arvelige og især ramte kvinder, kunne:

(...) på deres Vandring gennem Slægtled antage de mest vekslende Former. Fra en og samme Sygdomskilde kan hidledes Sindssygdom, Krampetilfælde, Ligfald, Lammelser, Hysteri og Hypokondri, Nervesvækkelse og Ekscentricitet. (Ribbing, 1891)

Aldersgrænsedebatten viste altså, at læger, hvad enten det var en skolehygiejniker som Hertel, en gynækolog som Howitz, eller arvelighedsforskeren Ribbing, så anskuede de ud fra hver deres faglige indfaldsvinkel pigerne som værende særligt svagelige i en ganske bestemt periode af deres liv, nemlig i puberteten; og de mente, at dette havde afgørende indflydelse på pigernes fremtid - og dermed også på slægtens, folkets, samfundets fremtid.

${ }^{7}$ Lov om de højere Almenskoler blev vedtaget i 1903. Set i sammenhæng med folkeskoleloven af 1898 var den udtryk for et enhedsskoleprincip, da man med den skabte begyndelsen til et sammenhængende uddannelsessystem, hvori alle havde en formel mulighed for at få en videregående skoleuddannelse. Disse to skolelove afløste det standsopdelte skolesystem. 
Den holdning, som var lægevidenskabeligt begrundet, nemlig at piger ikke kan præstere det samme intellektuelt som drenge, har afspejlet sig i skolelovgivningen i hvert fald op til sidst $\mathrm{i}$ 1950'erne, hvor pigerne stadig havde mulighed for at undgå visse hårde fag, som f.eks. matematik, til mellemskoleeksamen.

Figurer: Denne tredie debat viser os noget om grænser og overgange, der er nogle dybtliggende måder at tænke om tilværelsen på, som kendes i de fleste kulturer. Lægers optagethed af især pigers og kvinders biologi/sygdomme er gennemgående i perioden; den kommer til at markere deres anderledeshed og er med til at skabe en stærk afgrænsning imellem kønnene, hvorimod synet på puberteten som værende en generel fysisk svaghedstilstand, hvori der lurer særligt mange farer (beskrevet som skoleproblemer, forårsaget af onani, "følelsesfrembrud" o.lign.) er en fokusering på en overgang - fra barn til voksen.

I sundhedsskrifterne var der, som nævnt tidligere, i perioden fokus på en kropslig grænse: huden, som er det, der afgrænser mennesket, individet, fra det udenom. Den blev betragtet som:

(...) det Overtræk, hvormed det menneskelige Legeme er beklædt, og som tilmed, nærmere beset, viser sig at være forsynet med "Porer" (små Huller), hvorigennem de til Sundhedens Bevarelse nødvendige Uddunstninger foregå. (Fibiger, 1894, s. 34)

Åbningerne er de svage punkter i en grænse, og det, der kommer ud igennem dem og dermed befinder sig på grænsen, dvs. hverken er krop eller ikke-krop, slører og svækker den; derfor vil en kultur som den, vi beskæftiger os med, der lægger vægt på opdelinger og grænsemarkering, også søge at fjerne de "urenheder", som befinder sig på dens grænser, mener socialantropologen Mary Douglas (Douglas, 1976). Der menes her sved, snot, sæd, slim osv., og ikke mindst de døde hudceller. Der er i artiklerne mange ord for den handling at fjerne sådanne urenheder med det formål at gøre huden ren. F.eks. bør man efter daglig vask udføre "Frottering", "Gnubning", "Rubning", "Rivning", "Strygning", "Gnidning" osv. af huden.

Sammenholder man med skolebygningerne finder vi de samme figurer. Der er markeret grænser imellem de to køn med plankeværk og mure; den ydre grænse, skolens ydermure, er fremhævet med borter og friser; mens åbningerne heri, overgangene, især dørene, er særligt markerede i muren (ofte helt op til 3. sals højde) samt ved hjælp af udsmykninger. Disse indgangsporte er ikke uden videre til at overskride for en udenforstående, og det er heller ikke meningen (de Coninck-Smidt, 1987).

\section{Fælles for de tre debatter - endnu en figur}

En figur, som kan identificeres i de tre foregående debatter, kunne man kalde cirkulation. Den er en klassiker i forrige århundredes hygiejnelitteratur: ud over at skille ad var det at få til at cirkulere en logik i fremgangsmåden, både når læger gav råd angående byplanlægnmg, og når de beskæftigede sig med kroppens sundhed. Det var f.eks. den effektive adskillelse og cirkulation af kloak og vand, der blev anbefalet Københavns kommune af lægen Emil Hornemann i midten af 1800-tallet (Hornemann, 1847), og det var blodets, luftens, næringens omløb, der blev fokuseret på i artiklerne i datidens sundhedstidsskrifter. Når man opførte offentlige bygninger, beregnet på at rumme mange mennesker, var mulighederne for cirkulation af frisk luft og varm luft samt bortledning af fordærvet luft et vigtig sundhedsmæssigt krav (Meldahl, 1877-78). I den periode, jeg beskæftiger mig med, ser den ud til at være særlig fremtrædende, både materielt og åbenbart, og som førbevidste logikker. Vi kan f.eks. se på nogle af de ord, der bruges for den fare-tilstand, der opstår, når cirkulation ikke fungerer: "Blodoverfyldning" har vi været inde på i forbindelse med skrivedebatten; begrebet blev også brugt i forbindelse med onani, som bl.a. af den grund blev skarpt fordømt; "Forstoppelse", 
mente skolehygiejnikeren, kunne være en følge af dårlige skolemøbler; og i forbindelse med diskussionen af fælles undervisning tales der f.eks. om "usunde Sammenstimlinger" af piger $i$ pigeskolen; "Opsvulmninger af den $\varnothing$ vre del af Næsesvælgrummet" (polypper!) kunne være den egentlige årsag til dumhed i skolen; skrivningen og selve skriften skulle være "flydende" - ikke med stop, afbrydelser osv. Også de tegninger, som viser Københavns skolebygningers planløsning, kan læses som en strategi til at kontrollere, at eleverne ikke "forsamler" sig eller "hober sig op" i gange, på trapper og i forstuer (Siegumfeldt, 1992, s. 36-41). Jeg mener, at cirkulationsfiguren må med i en beskrivelse af den logik og de principper, som også Axel Hertels praktikker fungerede efter, fordi det er en logik, som ligger bag løsningen af sådanne problemer, som har med "Ophobning" osv. at gøre et $\emptyset$ nske om eller fors $\emptyset$ g på at kontrollere dette farlige.

\section{Lægepraktikkers inkorporering - og skolens logik}

Det ser altså for os i dag ud, som om de forskellige tekster og spor, som disse praktikker har efterladt, rummer bestemte figurer, som er karakteristiske for lægers og hygiejnikeres fremgangsmåde i perioden - eller man kunne også sige for den logik eller fornuft, som var mulig i det felt, som Axel Hertel måtte agerere i. En måde at forholde sig til dette på kunne være at anvende Pierre Bourdieus praktik-teori, som den er udfoldet i hans Outline of a Theory of Practice fra 1977 (se litteraturlisten). Ifølge denne stammer den karakteristiske fremgangsmåde fra aktørernes (eksempelvis Axel Hertels) specifikke habitus, som rummer netop en tilbøjelighed til at opfatte, forestille sig, vurdere og handle på de bestemte måder. De objektive livsbetingelser, siger Bourdieu, og mener i første omgang: $\varnothing$ konomiske, politiske, samfundsmæssige og klassemæssige, og i anden omgang: opdragelse, uddannelse/dannelse og profession, er alle faktorer, som er med til at danne den specifikke habitus. En hel lægestand vil i en bestemt grundlæggende forstand have den samme habitus - og Hertel har jeg karakteriseret som typisk for sin profession. Begrebet om habitus er et brugbart redskab, når man skal forsøge at "forstå" nogle praktikker. I stedet for at tale om, at disse er bevidst udtænkt af mennesker med bestemte forudsætninger el.lign., eller at sige, at de stammer fra de samfundsmæssige strukturer, og på den måde gøre mennesket til blot en bærer af disse strukturer, så placerer Bourdieu forklaringen midt imellem eller henover disse to synspunkter. Habitus er et teoretisk begreb; i vores habitus findes de objektive strukturer, vores livsvilkår, som principper eller logikker, der sætter sig igennem i fremgangsmåden for vore handlinger som strategier. Dette sætter nogle grænser for, hvad det er muligt at "finde på"; men den individuelle habitus giver også nogle muligheder for improvisation og dermed for ændring af vores livsvilkår. De omtalte logikker kan ikke direkte aflæses af praktikkerne, men de kan analyseres frem som nogle figurer, der er typiske for en vis fremgangsmåde med hensyn til en professions perception, vurdering, handling.

I skolen sker der en institutionaliseret opdragelse af børn, det vil sige, der sker en overføring af kultur fra en generation til den næste. Dette sker bevidst gennem skolens indhold og curriculum. Men det sker også "præ-bevidst" via de fysiske rammer: bygningerne, skolens møbler og møblering, dens ordensregler, metodikken og dennes forordnede bevægelser og kropsstillinger, samt på mange andre måder. Der er her tale om en overføring af logik i fremgangsmåder, som f.eks. sker non-verbalt og gennem kroppens påtvungne, eller udefra styrede, bevægelser. Det vil sige, at bagved eller under den åbenbare kommunikation, som er: dette er et sundt og godt opholdssted og nogle hygiejnisk korrekte møbler, ligger en indprentning af grundlæggende principper, som går på noget andet.

Hele tricket $i$ den pædagogiske fornuft ligger helt præcist $i$ den måde, som den fremtvinger det væsentlige på, mens den tilsyneladende forlanger det uvæsentlige. (Bourdieu, 1977, s. 94f; min oversættelse) 
Bourdieu mener f.eks., at der bag indprentningen af regler for skolens orden eller den rette siddestilling er gemt en overføring af nogle måder at opfatte verden på, bl.a. nogle hierarkiske principper. Det væsentlige ved skolen som institution er nemlig, at den, trods en relativ autonomi, reproducerer magtforholdene i samfundet.

Forskellige professioner havde indflydelse på skolens liv. Dens lærerkorps havde det selvfølgelig direkte, men også læger/hygiejnikere og de arkitekter, som byggede og indrettede de ny skoler, havde en vis indflydelse. De to sidstnævnte grupper har, ser det ud til, indbyrdes de samme logikker i fremgangsmåden for deres praktikker med skolen: at dele op, markere den/det enkelte, og lade cirkulere. Det stemmer med, hvis vi skal følge Bourdieus habitus-teori, at læger og arkitekter stammer fra samme samfundsklasse, har fået samme type opdragelse, har fået akademiske uddannelser, rejst med fagligt formål i udlandet m.m. De typiske figurer i deres habitus vil derfor til en vis grad være de samme, selvom principperne for deres faglige praktikker udmønter sig forskelligt: at tegne en skolebygning er noget andet end at analysere, hvordan dårlig ryg og nærsynethed kan undgås. Dette betyder, at deres arbejde har støttet og understreget inkorporeringen af de samme logikker. Lærerkorpset, derimod, som er det, der står i centrum for det synlige arbejde i skolen, bestod i perioden af forskellige grupper med forskellig baggrund og uddannelse (i modsætning til i dag). Spørgsmålet her er, hvorvidt man kan sige, at Axel Hertel og læge/skolehygiejniker-kulturen med dens påvirkning af skolens praktikker, som foregik bag kulisserne så at sige, overførte typiske fremgangsmåder fra deres habitus til børnene i de københavnske kommuneskoler og dermed modificerede deres (børnenes) måde at forstå verden på. Børnene i de københavnske kommuneskoler mødte nemlig op i skolen med nogle andre perceptions- og handlemønstre, der var blevet til som en inkorporering af nogle andre livsbetingelser: de var en anden generation, de stammede fra en anden samfundsklasse, havde en anden primær opdragelse og et andet hjemmeliv, andre fysiske omgivelser at bo og færdes i osv.

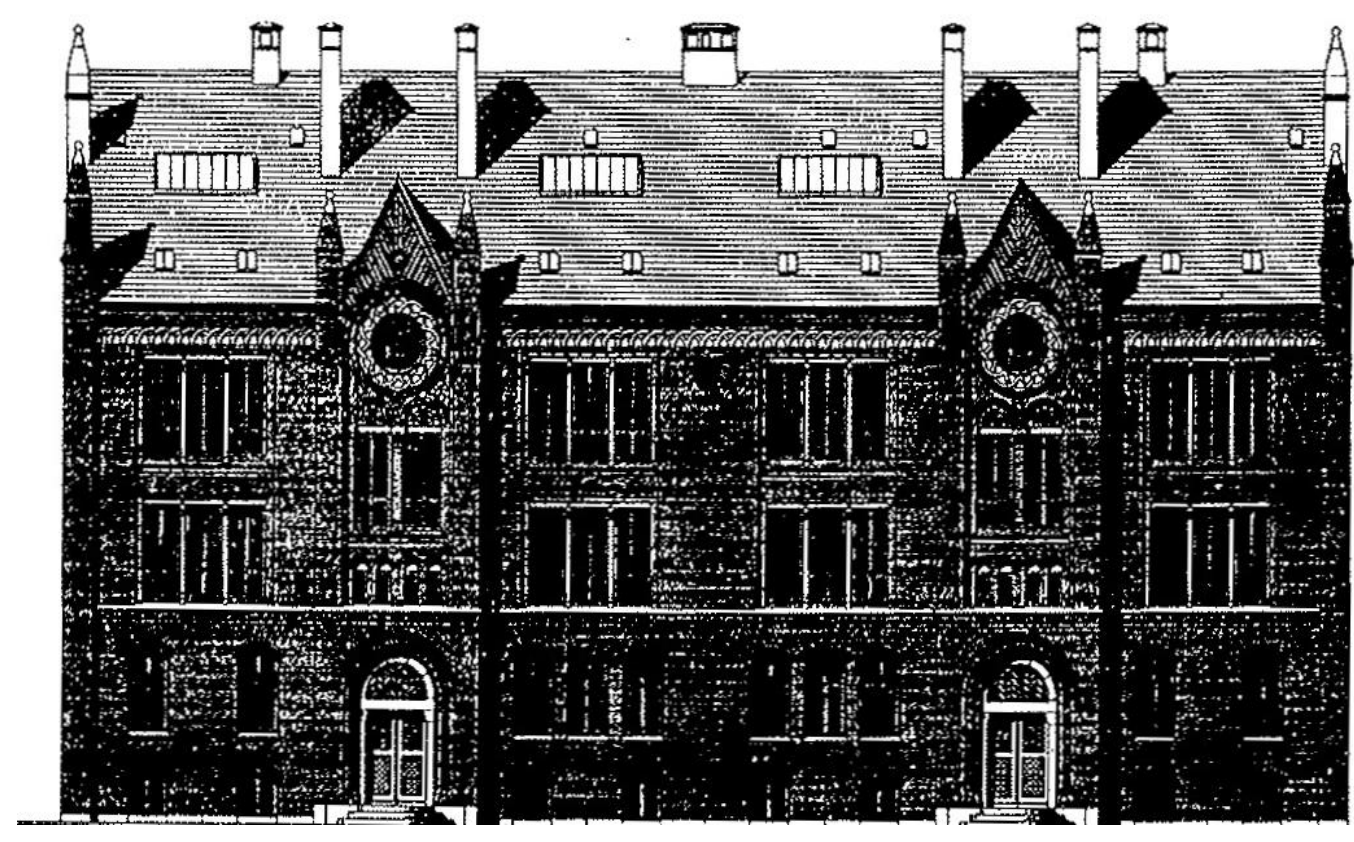

Figur 2: Kommuneskolen i Vestervoldgade, facade mod gården. Kilde: Dansk Skolemuseum, Christian Glenstrup. 
Inkorporering vil sige, at visse ting læres, blot som en kropslig overføring af "viden"; men hverken overføreren eller barnet har nogen viden om denne "viden". At gå til højre eller til venstre, afhængigt af ens køn, at skulle holde afstand til sidekammeraten og at se op på læreren, at holde sig klassevis i lige rækker, at skulle holde ryggen lige og stiv, fingrene ligeså (ved skrivning og når man "markerede sig" i klassen), at skulle være opmærksom på de enkelte lemmers bestemte vinkler i relation til bord og bog, at blive rettet ind efter lyset, at blive placeret efter fysisk handicap eller skolemæssig dygtighed. Alt dette inkorporerer en bestemt "viden" i barnet, en viden, som det først og fremmest har som en kropslig viden om klassificering og adskillelse og om markeringen eller fremhævelsen af den/det enkelte.

På samme tid blev der ved skolens særlige orden indprentet en "viden" om magt og hierarki og om den enkeltes plads i hierarkiet. Hvor der er skole, er der også en lærer og nogle børn; det er uomgængeligt i den forståelse af skole, vi her taler om. Læreren er den, der magter (dvs. er ansat til og derfor har magten til) at overføre kulturen til næste generation - der er altså et magtforhold og et hierarki, som inden for skolens særlige logik bl.a. kommunikeres ved den asymmetriske relation mellem lærer og elev, ved katederforhøjningen, vinduet i døren, glastaget i retiraden (så overvågning kan ske fra lærerværelset) samt ved elevernes indbyrdes placering i klasser og inden for klassen efter henholdsvis alder og dygtighed (evt. handicap som dårligt syn, hørelse el.lign.). Og den understreges ved de praktikker, hvis figur handler om ikke at stoppe op, men holde håndskriften "flydende", holde bevægelsen og fordelingen af elever "i gang" op igennem skolens trapper, gang og forstue, så man undgår det, der er til fare for denne orden: ophobningen, sammenstimlen af børn, brud i skriften, osv. Man kan sige, at det, vi her ser, er, at en bestemt social orden fastholdes ved en kulturel orden: skolens orden.

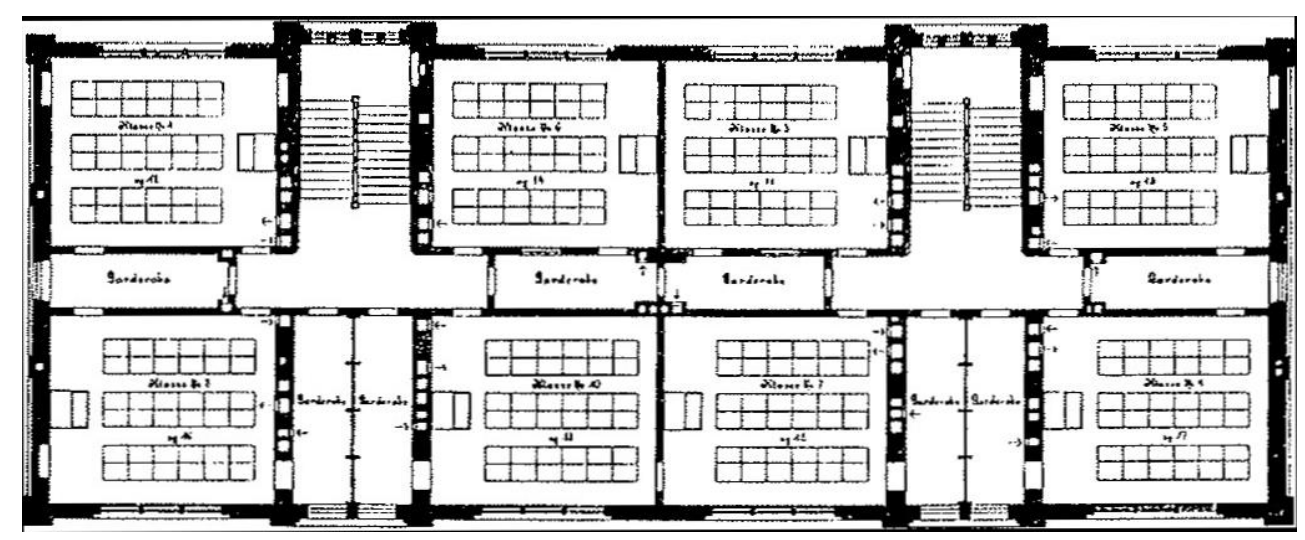

Figur 3: Kommuneskolen i Vestervoldgade, plan over 1. sal. Kilde: Dansk Skolemuseum, Christian Glenstrup.

\section{Konklusion}

Betydningen af skolehygiejnikernes arbejde med skolen ser vi for det første helt åbenlyst i form af bygninger, møblering, inventar, i direktiver for undervisning - såvel metoder som indhold skolelovsbestemmelser, oprettelsen af Den Skolehygiejniske Forening m.m. Dette arbejde havde til hensigt at indføre sundhedsmæssige forbedringer, som skulle føre til kraftigere, stærkere, mere livfulde og derfor mere overlevelsesdygtige mennesker for i sidste ende at fremme et sundt folk. Den lægevidenskabelige diskurs, dens forklarings- og tænkemåde, samt logikken i de skolehygiejniske praktikker blev, ser det ud til, anvendt ikke alene i det lægelige arbejde med skolens børn, men også ved arkitekters planlægning af skolernes fysiske rammer og i lærernes arbejde med undervisning. 
Praxeologi - Et kritisk refleksivt blikk på sosiale praktikker.

Dermed blev der med de skolehygiejniske forbedringer inkorporeret og overført nogle for lægestanden typiske logikker til eleverne - vel at mærke bagom lægers, arkitekters og læreres bevidste hensigter. Dette var med til at muliggøre, forstærke og understøtte den - hverken for børn eller voksne bevidste - indlæring af asymmetriske relationer, af hierarkisk ordning, overvågning og selvkontrol; en indlæring, som hørte til periodens skolemæssige orden og funktion. 


\section{Litteratur}

Betænkning (1884). Betænkning afgiven af den under 23. Juni 1882 nedsatte Kommission til at tilvejebringe Oplysninger om mulige sanitære Misligheder og Mangler i Ordningen af Skolevæsenet, og til at fremkomme med Forslag til saadannes fremtidige Forebyggelse. Ministeriet for Kirke- og Undervisningsvæsenet.

Betænkning (1896). Betænkning angaaende Skriveundervisningen, afgivet til pædagogisk Selskab ved det af Selskabet nedsatte Udvalg. Pædagogisk Selskab

Bourdieu, P. (1977). Outline of a Theory of Practice. Cambridge University Press.

de Coninck-Smidt, N. (1987). "Haderslevgadesage". I: Årbog for Arbejderbevægelsens Historie, nr. 17, SFAH, København.

Douglas, M. (1976). Naturlige symboler. København: Nyt Nordisk Forlag Arnold Busch, s. 7-17.

Fibiger, E. (1894). Sundhedslære for Hjem og Skole på Land og i Købstæderne. København: Thaning og Appel.

Hertel, A. (1880). Vort Skolemateriel. Berlingske Tidende, 8. og 9. april samt 20. og 24. april, København.

Hertel, A. (1883). De hygiejniske Forhold i Skolerne i nogle st $ø$ rre Byer i Udlandet. Vor Ungdom.

Hertel, A. (1892); Lodret eller skraa Skrift ved Skriveundervisning i Skolerne. Vor Ungdom, I - II.

Hertel, A. (1894). Nyere Undersøgelser om Udviklings- og Sygdomsforhold i Barnealderen og disses Betydning for Skolen. Foredrag holdt i Det pædagogiske Selskab. Vor ungdom, I.

Hertel, A. (1902). Det nye Lovforslag til en Skolereform. Vor Ungdom, VI.

Hertz, P. (1928). Axel Hertel. Skolehygiejnens Skaber i Danmark. Tidsskrift for Skolehygiejne, XVI.

Hornemann, E. (1847). Om adskillige Mangler ved den offentlige Reenlighed i Kiøbenhavn, i sanitær Henseende; og om en forbedret Vandforsyning som et Middel derimod. København: Gyldendal.

Kirkebæk, B. (1993). Da de åndssvage blev farlige. Holte: Forlaget SocPol.

Kjøbenhavns Magistrat (1881-1906). Kjøbenhavns Kommuneskoler 1846-1903, ved Foranstaltning af Kjøbenhavns Magistrat. Text og Tegninger. Bind 111.

Kraft, L. (1913). Lægeportrætter fra det 19. Århundrede. Kjøbenhavn: G. \& C Gads Forlag.

Levy, F. L. (1879). Om Skolehygiejnen. Vor Ungdom, I.

Meldahl, F. (1877). De hygiejniske Forhold i nogle offentlige og private Bygninger, samt Lægers og Bygmestres Stilling til Løsningen af de her foreliggende Opgaver. I: Hygiejniske Meddelelser, Ny Række.

Mehldahl, F. (1879-80). Belysningsforholdene seet fra Øienhygieinikerens Standpunkt. I: Hygiejniske Meddelelser, Ny Række.

Paludan, H. (1990). Cairos røde rose. Noget om historikernes kildebegreb. Den jyske historiker, nr. 50. Petersen, K.A. (red.)(1995). Praktikteori i sundhedsvidenskab. København: Akademisk Forlag.

Ribbing, S. (1891). Med hvem tør man gifte sig følge Arvelighedslærens Love? Christiania, København: Alb. Commerneyers Forlag.

Rosenbeck, B. (1987). Kvindekøn. København: Gyldendal.

Schmidt, L.-H. \& Kristensen, J. (1986). Lys, luft og, renlighed. Den moderne socialhygiejnes fødsel. København: Akademisk Forlag.

Siegumfeldt, B. (1992a). Renhed og Rammer. Lægers og arkitekters arbejde med ny folkeskoler $i$ København 1880-1900. Forskningsnoter, nr. 10, Institut for Pædagogik, Københavns Universitet. 
Siegumfeldt, B. (1992b). Adam og Eva skrev sandsynligvis lodret! Dansk pædagogisk Tidsskrift, nr. 2.

Siegumfeldt, B. (1988). En analyse af nogle pædagogers og opdrageres syn på krop, køn, seksualitet-med udgangspunkt i forskellige tekster, der alle har omdrejningspunkt i dét fællesskoleprincip, der blev indført ved Lov om højere Almenskoler fra 1903 - og analyseret bl.a. ved hjælp af Mary Douglas' teorier om renhed og urenhed. Eksamensopgave fra Center for Kvindeforskning, Københavns Universitet.

Ulrichsen, H.O. (1893). Skrivebog for Skole og Hjemmet, med lodret Skrift. Bogen forefindes på Dansk Skolemuseum, København.

Ulrik, A. (1880). Om nogle hygiejniske Hovedpunkter ved Opdragelse og Undervisning. Vor Ungdom, I - II. 